\title{
Ruslands politik i Arktis
}

Af Ekaterina Klimenko

Camerons Forværringen af forholdet mellem Rusland og dets arktiske naboer skyldes hovedsageligt forhold uden for regionen. Den afspejler sig i slagkraftig russisk sikkerhedsretorik om Arktis, men man overfortolker, hvis man betragter Ruslands militære aktiviteter i regionen og sikkerhedsretorikken som tegn på russisk intention om at trække nye grænser eller anspore til konflikt i Arktis. Ruslands militære politik i Arktis er en del af en bredere udenrigs- og sikkerhedspolitik, og Ruslands militære ekspansion og fremtiden for samarbejdet i regionen vil i høj grad blive afgjort ikke kun af Ruslands forbindelser med de arktiske naboer, men også af den globale geopolitiske situation.

Et stigende antal stemmer i medierne og i politiske og forskningsmæssige kredse har siden 2007 udtrykt bekymring for, om der vil opstå territoriale konflikter eller en kamp om ressourcer i Arktis. Men virkeligheden er den, at Arktis har nydt godt af et hidtil uset niveau af samarbejde i det seneste årti, ikke mindst på grund af Den Russiske Føderations overraskende konstruktive tilgang.

Den russiske regering har siden anden halvdel af 00'erne samarbejdet konstruktivt i hele den arktiske region. Rusland har været stærkt engageret i udviklingen af energiressourcer og skibsfart. De fleste russiske embedsmænd har distanceret sig fra sikkerhedsretorik om Arktis, og de statslige russiske arktiske strategier har understreget, at Rusland ser regionen som en særlig zone, hvor et fælles ønske om fred og internationalt samarbejde forebygger spændinger.

Krisen i Ukraine, som eskalerede i begyndelsen af 2014, og den voksende splittelse mellem Rusland og Vesten, har til gengæld ført til fornyet bekymring over risikoen for konflikt i Arktis og militarisering af regionen. Siden starten af krisen i Ukraine har sikkerhedslandskabet i Arktis været skiftende, og det rejser en række centrale spørgsmål, herunder: Hvad er målene for Ruslands politik i Arktis? Hvilke sikkerhedsbekymringer har Rusland i den arktiske region? Hvordan har Rus-

Ekaterina Klimenko er forsker ved Stockholm International Peace Research Institute 

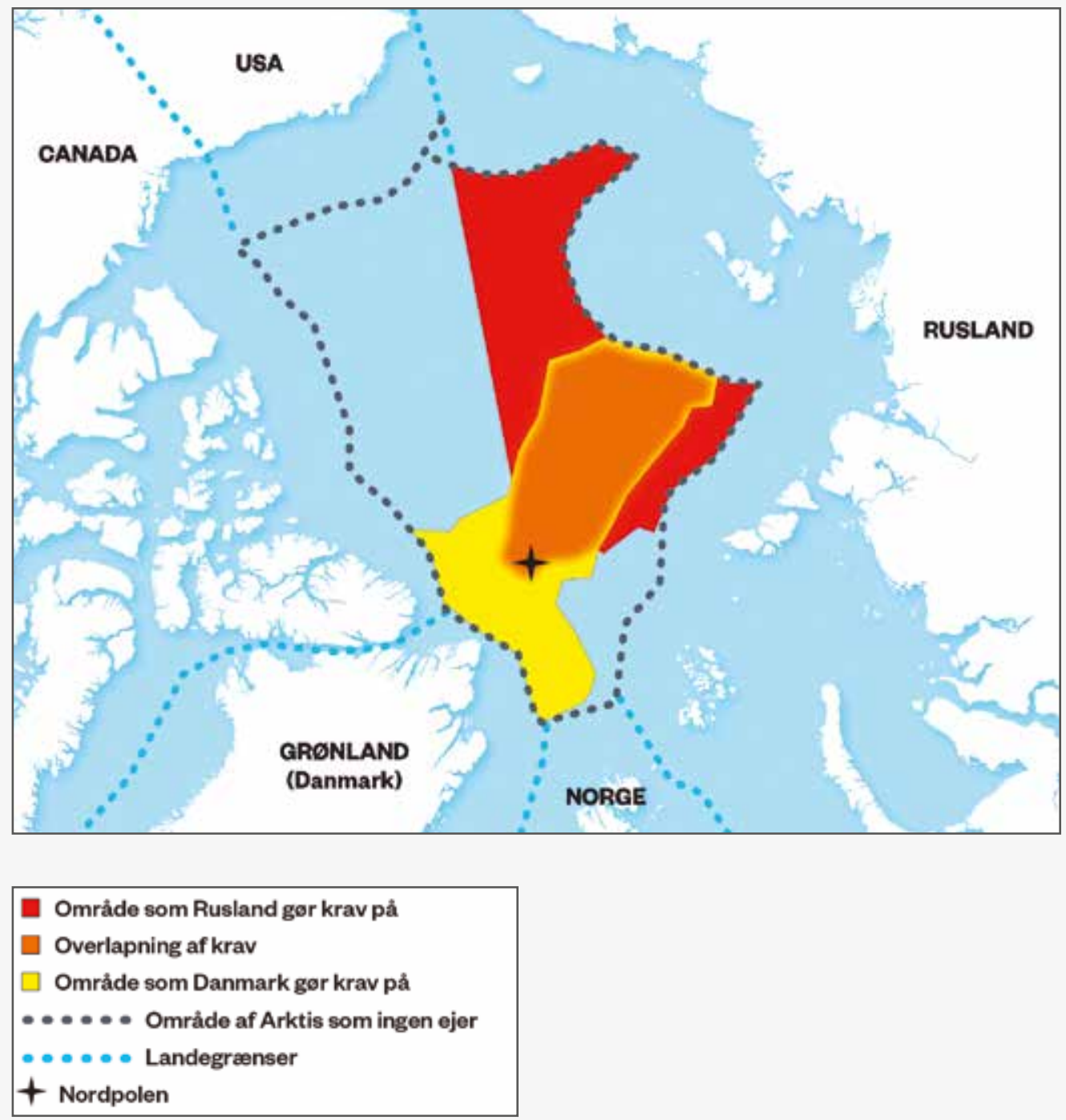

venligst stillet til rådighed af Information/iBureauet[ 
lands retorik om Arktis udviklet sig i de senere år? Kan det arktiske samarbejde overleve konsekvenserne af det køligere forhold mellem Rusland og dets arktiske naboer?

\section{Olie og rivalisering}

To russiske doktriner, Foundations of the Russian Federation's State Policy in the Arctic until 2020 and beyond (2009), samt The Strategy for the Development of the Arctic Zone of the Russian Federation and National Security (2013) udpegede udvikling af olie og gas og skibsruter som Ruslands vigtigste interesser i regionen. Særligt fremhævedes den arktiske zone som en strategisk ressourcebase; sikring af Arktis som en zone med fred og samarbejde; Den Russiske Føderations brug af Nordøstpassagen som et nationalt integreret transport-kommunikationssystem i Arktis.

Allerede i 2008 annoncerede daværende præsident Dmitrij Medvedev, at Arktis vil blive Ruslands ressourcebase i det 21. århundrede. Ifølge Ruslands energistrategi frem til 2030 vil udvikling af energifelter i de arktiske farvande og på land skulle kompensere for den nedgang i gas- og olieproduktionen i det vestlige Sibirien, som allerede kunne noteres i 2015. Den russiske arktiske sokkel indeholder op til 5-9 pct. af de flydende kulbrinteressourcer i Den Russiske Føderation (hvoraf mindst 2 pct. er olie) og op til 12,5 pct. af gasressourcerne. Den arktiske zone indeholder også betydelige ressourcer på land. Gasressourcerne på Yamal-halvøen alene er på 505.569 mia. kubikmeter, mens reserverne er på 10.847 mia. kubikmeter. De samme tal for olie er henholdsvis 4.144 mio. ton og 2.921 mio. ton.
Kun to russiske selskaber har lov til at arbejde off-shore på den russiske arktiske sokkel. Men da Rusland ikke har den fornødne teknologi, og da de høje omkostninger er parret med lange udsigter til et matchende afkast, kan de statslige russiske selskaber Rosneft og Gazprom ikke på egen hånd udvikle den arktiske sokkel, men er nødt til at inddrage udenlandske samarbejdspartnere.

I 2008 underskrev Gazprom, Statoil og Total derfor en aftale om at udvikle Shtokman-feltet i Barentshavet. I 2011 underskrev Rosneft en strategisk samarbejdsaftale med ExxonMobil om at udforske dets licenser i Karahavet. I 2012 underskrev Rosneft en række aftaler om etablering af joint ventures for udviklingen af den arktiske sokkel med Statoil (Barentshavet og Det Okhotske Hav) og Eni (Barentshavet).

Siden har forskydninger på verdens energimarkeder imidlertid sået tvivl om den fremtidige udvikling. Den amerikanske skifergas-revolution og Den Europæiske Unions planer om at prioritere diversificering af gasleverandører har sat Ruslands forslag om at udvikle Shtokman-feltet på hold, og partnerskabet mellem Gazprom, Statoil og Total faldt fra hinanden i 2012.

Derudover vil udviklingen af de arktiske sokkel-oliefelter være urentable, så længe prisen på olie forbliver under 70 dollar per tønde. I januar 2016 sank oliepriserne til en bundrekord på 27,67 dollar, det laveste siden 2003 - og medmindre olieprisen igen stiger til 100 dollar per tønde forventes olieressourcerne på den arktiske sokkel at forblive uudviklede.

Endelig har de sanktioner som EU og USA har indført mod Rusland i forbin- 
delse med Ruslands handlinger i Ukraine, medført at energisamarbejdet med de udenlandske partnere om den arktiske sokkel er blevet suspenderet. Sanktionerne forhindrede de amerikanske og europæiske selskaber i at tage del i dybtvandsoffshore-projekterne i Rusland og i at levere udstyr, teknologi og finansiering.

Rosneft måtte stoppe geologisk udforskning af den arktiske sokkel og erklærede, at det ikke ville være i stand til at genoptage planlagte boringer i Karahavet i 2015, eftersom dets partnere, ExxonMobil og North Atlantic Drilling (NADL), var forhindret af sanktionerne. Uden Exxons platform og NADELs semisubmersible rigge (halvt nedsænkbare platforme, red.) har Rosneft været tvunget til at sætte en stopper for et konkret projekt. Skønt direktøren, Igor Sechin, i oktober 2014 hævdede, at virksomheden var klar til at udføre forskningen på egen hånd, lader det til, at Rosneft kun vil være i stand til at fortsætte den seimiske eftersøgning, men ikke egentlige efterforskningsboringer uden udenlandsk teknologi.

Som et resultat heraf, er det eneste fungerende projekt på den russiske arktiske sokkel i øjeblikket Gazprom Nefts Prirazlomnoye-oliefelt i Pechora-havet (60 km ud for kysten), der blev operationelt i december 2013. Over 1,1 mio. tons olie blev afsendt fra Prirazlomnoye-feltet i 2014-2015.

Udviklingen af de arktiske ressourcer på land er primært koncentreret om Yamalhalvøen. I 2012 påbegyndte Gazprom produktionen på Bovanenkovo-gasfeltet, der dog er reduceret kraftigt i forhold til den oprindelige plan på grund af faldende efterspørgsel.

Gazprom Neft arbejder på Novy Port, et af de største olie- og gasfelter på Yamal- halvøen, med en potentiel kapacitet på 250 mio. tons olie. Det private russiske selskab Novatek er i gang med at anlægge et naturgas-anlæg, Yamal LNG, med en samlet kapacitet på 16,5 mio tons flydende naturgas om året. Yamal LNG vil være delvist i drift ved udgangen af 2017, og fuld kapacitet nået i 2021.

Sanktionerne har også påvirket onshore udviklingen, men her var problemerne mest af finansiel karakter. Novatek er på sanktionslisten og står over for betydelige problemer med at finde penge til sit Yamal LNG-projekt på de vestlige finansmarkeder. Problemet løses efter sigende ved et skifte til kinesiske investeringsinstitutter.

\section{Nordøstpassagen: Mere indenlandsk end international}

Ruslands to arktiske strategier sigter begge på udvikling af Nordøstpassagen til indenlandsk såvel som international sejlads. Den Russiske Føderations transportstrategi understreger Nordøstpassagens betydning for kommerciel skibsfart i de arktiske farvande, for udvikling af ressourcerne på den arktiske sokkel og territorierne i den arktiske zone samt for adgangen til Ruslands fjerneste nordlige områder.

Transportstrategien fastlægger en række tiltag til udvikling af den kystnære infrastruktur langs Nordøstpassagen, eftersøgnings- og redningstjenester, isbrydningsfaciliteter osv.

Modernisering af den russiske isbryderflåde er en topprioritet. Bygningen af tre atomdrevne LK-60 isbrydere, tre dieseldrevne LK-25 isbrydere og en række mindre isbrydere og isbryder-støtteskibe er planlagt frem til 2020. De russiske private og statslige virksomheder opbygger hver deres egne isbryderflåder. 
Transportstrategien forudser også opførsel af nye havne og omladningsfaciliteter til brug for olien og gassen i Arktis, og så peger den på modernisering af havnene i Dixon, Tiksi og Pevek til redningsog forskningsfartøjer; opførelse og modernisering af kystnært navigationsudstyr; kortlægning af den arktiske havbund langs ruterne for transport af olie og gas; genetablering af en flåde af mindre privatopererede fly, der skal forbedre adgangen til fjerne nordligt beliggende russiske områder og bistå med eftersøgnings- og redningsoperationer.

En føderal lov fra 2012 styrkede administrationen af skibsfarten - herunder især håndtering af ansøgninger om sejllads i Nordøstpassagen, overvågning af is- og navigationsforhold, sikkerhedskrav, isbryder-lodsning af skibe mv. Loven har også introduceret en række søfartsregler i området omkring Nordøstpassagen.

I juni 2015 lancerede den russiske regering så et omfattende projekt for yderligere udvikling af Nordøstpassagen fra 2015 til 2030. Projektet omfatter navigation-hydrografisk og hydro-meteorologisk støtte til skibe, eftersøgnings- og redningsassistance, udvikling af havne og sikring af forsvaret af Nordøstpassagen. En del detaljer er ikke offentligt tilgængelige, da det drejer sig om sikkerhedsspørgsmål.

Selv om der var megen snak om Nordøstpassagens potentiale for international transitskibsfart, så er udviklingen af Nordøstpassagen især forbundet til den indenlandske skibsfart og især olien og gassen på Ruslands arktiske sokkel. Ifølge minister Sergei Donskoy vil den interne transport mellem forskellige havne i den russiske arktiske zone udgøre op til 80 pct. af skibsfarten langs Nordøstpassagen. Især udviklingen af Novateks Yamal LNG og Gazprom Nefts depoter i Novy Port ventes at føre til øget trafik. Omsætningen på skibsfart forventes at stige til 30 mio. tons i løbet af de næste 5-10 år. I 2015 var omsætningen på 5,4 mio. tons, hvilket var en stigning på 45,4 pct. sammenlignet med 2014.

Statistikken for de seneste fem år viser også en stigende interesse for international transit både fra russiske og internationale rederier, men foreløbig mest som eksperimenterende forsøg. Transitskibsfarten er reelt faldet i 2014 og 2015 . Kun 39.586 tons gods blev transporteret via Nordøstpassagen i 2015, hvilket er næsten syv gange mindre end i 2014 .

Af de 18 fartøjer, som brugte Nordøstpassagen som transitrute i 2015, var de 10 russiske, to kinesiske, et hollandsk og et svensk. Manglen på tilstrækkelig infrastruktur og høje forsikringsudgifter gør det vanskeligt at udvikle bæredygtig skibsfart gennem Nordøstpassagen.

\section{Udvidelse af kontinentalsoklen}

Rusland har understreget sin støtte til UNCLOS, FN's Havretskonvention, som blev ratificeret i 1997. I 2001 indsendte Moskva det første krav nogensinde på udvidelse af kontinentalsoklen til Kommissionen for Kontinentalsoklens Grænser (CLCS). Rusland gjorde gældende, at de to undersøiske bjergkæder, Mendelejevryggen og Lomonosovryggen, er fortsættelser af Ruslands kontinentale sibiriske sokkel. Hvis kravet bliver accepteret vil det øge Ruslands kontinentalsokkelområde med 1,2 millioner kvadratkilometer.

Kommissionen afviste kravet og bad om mere videnskabelig dokumentation. 
Siden da har påvisning af rettighederne til Lomonosovryggen og Mendelejevryggen været blandt Ruslands højeste strategiske prioriteter i Arktis - også i de to førnævnte doktriner. Vladimir Putin har ved flere lejligheder understreget betydningen af dette arbejde, blandt andet på et møde i FN's Sikkerhedsråd, hvor han understregede: "Den juridiske formalisering, i overensstemmelse med international ret, af de ydre grænser for Ruslands kontinentalsokkel i det Arktiske Ocean, er et presserende problem, der kræver omhyggeligt arbejde".

Rusland har de sidste 12 år gennemført 10 videnskabelige ekspeditioner for at indsamle oplysninger til ansøgningen, blandt dem den berømte Arktika 2007, som tiltrak stor international opmærksomhed, da det russiske flag blev plantet på havbunden ved Nordpolen.

Den Russiske Føderation indgav sin reviderede ansøgning i august 2015. Ifølge Kommissionen vil ansøgningen blive behandlet i foråret 2016.

\section{Sikkerhed i Arktis}

Russiske embedsmænd forventer ikke konflikter over ressourcer eller territorier i Arktis. På trods af de nuværende spændinger mellem Rusland og Vesten har udenrigsminister Sergej Lavrov understreget, at "den nuværende komplicerede internationale situation medfører ingen fundamentale ændringer i den etablerede orden".

Gennem det meste af det seneste årti tog de fleste russiske embedsmænd afstand fra sikkerheds-baseret retorik om Arktis. De understregede i stedet, at Moskva ser Arktis som en særlig zone for internationale relationer, men i takt med at forholdet til Vesten er forværret, har
Ruslands retorik omkring Arktis ændret sig væsentligt, og øgede trusler mod Ruslands nationale sikkerhed og interesser i regionen er blevet fremhævet. Det har også afspejlet sig i officielle dokumenter. Opgaven med at "beskytte russiske interesser i Arktis" dukkede for første gang op i den Russiske Militærdoktrin i 2014. Doktrinen peger på udvidelsen af NATOs kapaciteter, der udstyrer NATO med globale funktioner gennem overtrædelse af de internationale retsnormer, og som flytter NATO-landes militære infrastruktur tættere på Rusland, som den vigtigste militære trussel for Rusland.

Nye tilføjelser fra juli 2015 fokuserer på Arktis og Atlanterhavet. NATOs globale aktiviteter ses som den største sikkerhedsbekymring i Atlanterhavet, mens Arktis især er væsentlig pga. den russiske Nordflådes uhindrede adgang til Atlanterhavet. Derudover understreger den Maritime Doktrin, at det vigtigste mål for den arktiske politik er at mindske truslerne i den arktiske region. Dette skal blandt andet opnås gennem en styrkelse af Nordflåden.

De to førnævinte arktiske doktriner fra 2009 og 2013 sigter særligt mod at forbedre grænsekontrolssystemet, udvikle grænseinfrastruktur, og oprette et nødberedskab. For eksempel har Ruslands føderale sikkerhedstjenestes grænsepoliti etableret nye afdelinger for de Vest- og Østarktiske områder i henholdsvis Murmansk og Petropavlovsk-Kamchatsky.

I 2009 blev grænsekontrolanlægget Nugurskaya etableret på Franz Josefs Land, en øgruppe nord for polarcirklen. Der er planer om at oprette tilsvarende anlæg længere mod øst på Wrangeløen samt syv målestationer langs den arktiske 
kyst. I 2009 afsatte Rusland 910 mio. rubler til opførelse af ti eftersøgnings- og redningsoperationscentre langs Nordøstpassagen. De første tre centre er blevet åbnet i Naryan-Mar, Dudinka og Arkhangelsk.

Historisk set har Ruslands arktiske militære kapacitet og infrastruktur været en væsentlig del af de strategiske nukleare styrker og luftforsvarssystemer, der giver Rusland strategisk balance i forhold til USA og NATO. I de senere år har den nukleare afskrækkelse også fået øget betydning i Ruslands strategiske planlægning, især siden NATOs udvidelse i Østeuropa.

Et andet fokus for Ruslands militære oprustning i Arktis er derfor modernisering af Ruslands strategiske nukleare styrker og Nordflåden såvel som genoplivning af den nødvendige infrastruktur for at drive sådanne kapaciteter. Med The State Armaments Program 2020 (GPV 2020), vedtaget i 2010, opgraderer Rusland den strategiske ubådsflåde ved at erstatte Sovjet-æraens atombestykkede ubåde med den nye Borei-klasse ubåde, der er udstyret med en ny type ballistiske robotter. Den første ubåd, Yury Dolgoruky, blev indlemmet i Nordflåden i 2013.

Rusland genåbner også flyvepladser og radarstationer i Arktis til gendannelse af det luftforsvar, som blev afmonteret efter afslutningen på den kolde krig. Grupperinger af luftforsvarsstyrker er allerede blevet dannet i Ruslands ø-områder i Arktis, herunder Novaja Zemlja, de Nysibiriske øer, og Wrangeløen, samt ved Cape Schmidt. I december 2014 blev Joint Strategic Command North etableret til koordinering af de forskellige militære afdelinger i Arktis.
Fra og med 2012 har Rusland også øget antallet af militære øvelser i området. De største arktiske øvelser fandt sted i marts 2015, og involverede 38.000 soldater, 3.360 køretøjer, 41 flådefartøjer, 15 ubåde, og 110 fly. Blandt de seneste øvelser var en øvelse på Tajmyrhalvøen i august 2015, der involverede mere end 1.000 militærfolk og 12 fly. Øvelsen gjaldt forsvaret af et vigtigt industrielt objekt, terrorangreb og menneskeskabte og teknologiske nødsituationer.

Øvelsesscenarierne viser, at de militære styrker i Arktis fokuser på en lang række opgaver, lige fra traditionelle militære scenarier til relativt nye scenarier om sikkerhed i skibsfarten og forsvaret af olieog gasprojekter.

\section{Overdrivelser}

Ruslands nylige militære oprustning i Arktis bør ikke overdrives. Selvom sikkerhedsretorikken er taget betydeligt til gennem de seneste to år, viser udviklingen af de militære og paramilitære kapaciteter i Ruslands Arktis, at målene for russisk sikkerhedspolitik og militære styrker forbliver de samme. De omfatter især sikring af Ruslands suverænitet, beskyttelse af grænser og havområder og strategisk afskrækkelse af NATO og USA.

Selvom den seneste stigning i militære aktiviteter i Ruslands arktiske region har fundet sted efter at krisen i Ukraine brød ud, ville det være en fejltagelse at opfatte det som Ruslands reaktion på krisen. De fleste af de planer, som Kreml gennemfører i Arktis, blev annonceret længe før krisen i Ukraine i de Arktiske Strategier og GPV 2020. Væsentlige stigninger i militære aktiviteter i 2014-2015 er et resultat af den langsigtede politik for 
modernisering og omstrukturering af de russiske væbnede styrker, som endelig er begyndt at producere nogle håndgribelige resultater. Omfanget af militære aktiviteter i Arktis er stadig meget beskedent i forhold til Sovjettiden.

Det forventes desuden, at de fleste af Ruslands fremtidige militære udgifter og indkøb vil være rettet mod andre regioner end den arktiske. Siden krisen i Ukraine har der især været betydeligt fokus på opgradering af Sortehavsflåden og styrker placeret i Krim. Desuden vil den økonomiske krise som Rusland står overfor sandsynligvis resultere i forsinkelser for den militære oprustning i Arktis.

\section{Konklusioner}

I løbet af de sidste syv år har Rusland fokuseret på at udvikle de arktiske energiressourcer og Nordøstpassagen samt at styrke og modernisere det russiske militær og paramilitære styrkers kapacitet i forhold til nye sikkerhedstrusler og behovet for strategisk afskrækkelse.

Rusland har været en ansvarlig og i det store hele samarbejdsvillig arktisk spiller, bekræftet af Ruslands opbakning til det internationale retsgrundlag, der gælder i Arktis. En opbakning, der illustreres af, at Rusland har gjort en betydelig indsats for at indsamle verificerbare videnskabelige data som basis for sin ansøgning vedrørende kontinentalsoklen. Rusland indgav sin ansøgning, mens krisen i Ukraine var på sit højeste.

Rusland er både interesseret i og afhængig af at fortsætte samarbejdet med dets arktiske naboer, da det ikke er i stand til at udvikle sine arktiske ressourcer uden udenlandsk teknologi. Russiske selskaber har få eller ingen alternativer til vestlige partnerskaber.

Forværringen af forholdet mellem Rusland og dets arktiske naboer, som hovedsageligt skyldes forhold uden for regionen, afspejler sig i slagkraftig russisk sikkerhedsretorik om Arktis, men man overfortolker, hvis man betragter Ruslands militære aktiviteter i regionen og sikkerhedsretorikken som tegn på russisk intention om at trække nye grænser eller anspore til konflikt i Arktis.

Ruslands militære politik i Arktis er en del af en bredere udenrigs- og sikkerhedspolitik, og Ruslands militære ekspansion og fremtiden for samarbejdet $\mathrm{i}$ regionen vil i høj grad blive afgjort ikke kun af Ruslands forbindelser med de arktiske naboer, men også af den globale geopolitiske situation. Krisen i Ukraine må forventes at øge afstanden mellem Rusland og de øvrige arktiske stater i den nærmeste fremtid.

Samtidig er det dog vigtigt at bemærke, at samarbejdet på nogle områder fortsætter. Faktisk ser nogle iagttagere Arktis som et af de få områder, hvor samarbejde med Rusland er en nødvendighed og derfor bør fremmes. De fem arktiske kyststaters underskrivelse af erklæringen om forebyggelse af ureguleret fiskeri i det centrale Arktiske Ocean i juli 2015 bekræfter deres gensidige interesse $\mathrm{i}$ samarbejde. Man må håbe, at disse og lignende initiativer vil øge det arktiske samarbejde også på længere sigt.
(Oversat fra engelsk af Ane Dalegaard Hansen) 